\title{
Impact of solar irradiation on cholera toxin secretion by different strains of Vibrio cholerae
}

AUTHORS:

Cornelius C. Ssemakalu ${ }^{1}$

Le Roux Woulter ${ }^{2}$

Michael Pillay ${ }^{3}$

\section{AFFILIATIONS:}

Department of Chemistry, Vaal University of Technology, Vanderbij|park, South Africa

${ }^{2}$ Natural Resources and the Environment, Council for Scientific and Industrial Research, Pretoria, South Africa

3Department of Biosciences, Vaal University of Technology, Vanderbij|park, South Africa

\section{CORRESPONDENCE TO:}

Cornelius Ssemakalu

\section{EMAIL:}

Canzazu@gmail.com

\section{POSTAL ADDRESS:}

Department of Chemistry, Vaal University of Technology, Private Bag X201, Vanderbijlpark 1900, South Africa

\section{DATES:}

Received: 08 Mar. 2013

Revised: 24 Apr. 2013

Accepted: 25 Apr. 2013

\section{KEYWORDS:}

solar disinfection; SODIS;

cholera; cholera toxin;

Vibrio cholerae

\section{HOW TO CITE:}

Ssemakalu CC, Woulter L, Pillay M. Impact of solar irradiation on cholera toxin secretion by different strains of Vibrio cholera. S Afr J Sci. 2013;109(9/10), Art. \#2013-0061, 6 pages. http://dx.doi.org/10.1590/ sajs.2013/20130061

\section{(c) 2013. The Authors.}

Published under a Creative Commons Attribution Licence.
Cholera toxin is the aetiological agent of cholera - a deadly waterborne disease acquired through the consumption of untreated water contaminated with CTXФ bacteriophage harbouring strains of $V$. cholerae. Solar disinfection is a re-emerging technique that relies on the ultraviolet component of sunlight to inactivate the growth of Vibrio cholerae in water, rendering the water microbiologically safe for consumption. However, studies have shown that DNA damaging agents, such as ultraviolet light, induce the replication of the CTXФ bacteriophage with subsequent expression of the cholera toxin. In this study we investigated the impact of solar irradiation on the secretion of cholera toxin by toxigenic strains of $V$. cholerae in water. The cholera toxin ELISA assay, qualitative and quantitative real-time PCR as well as growth on solid media were used to determine cholera toxin secretion, DNA integrity and growth of the bacteria after $7 \mathrm{~h}$ and $31 \mathrm{~h}$ of solar irradiation. Solar irradiation in water reduced the integrity of DNA, inactivated the growth of $V$. cholerae and, most importantly, prevented the secretion of detectable levels of cholera toxin. This finding is encouraging for resource-poor communities that may rely on solar disinfection to alleviate the burden of cholerarelated fatalities.

\section{Introduction}

Cholera is a life-threatening waterborne disease caused by Vibrio cholerae, a motile Gram-negative bacterium that is autochthonous in natural aquatic ecosystems. ${ }^{1}$ The disease is a constant threat and continues to ravage resource-poor communities around the world that lack adequate access to safe potable water and sanitation, with subsequent high fatality rates ${ }^{2,3}$ Seven cholera pandemics have been reported worldwide; six were ascribed to the classical biotype of the 01 serogroup of $V$. cholerae while the most recent pandemic was attributed to the El Tor biotype of the same serogroup. Another serogroup of $V$. cholerae (0139) has been implicated in cholera outbreaks in some parts of Asia., 4

It has been hypothesised that only $V$. cholerae serogroups 01 and 0139 are capable of causing cholera outbreaks. However, this notion is changing as some non-01/0139 strains of $V$. cholerae have been reported to harbour the CTXФ bacteriophage genes ${ }^{6,7}$ providing them with the potential to cause cholera outbreaks. The CTXФ bacteriophage contains the genes responsible for the production of the cholera toxin - the aetiological agent of cholera. ${ }^{8,9}$ Cholera toxin is a multi-subunit ADP-ribosylating toxin that binds to the GM1 ganglioside of the intestinal epithelial cells. The toxin is made up of the cholera toxin A subunit, which consists of a single unit, and cholera toxin $B$, which contains five units. ${ }^{10}$ The subunits are produced in the bacterial cytoplasm and are transported to the periplasm where they are folded and assembled into the $84-\mathrm{kDa}$ heterohexameric AB5 toxin complex. ${ }^{11}$

The culturability of a variety of waterborne pathogens has been shown to be inhibited by solar radiation, specifically its ultraviolet component, ${ }^{12-14}$ thereby reducing the risk associated with the acquisition of deadly water-related infections. ${ }^{15,16}$ The mechanisms through which solar ultraviolet radiation (SUVR) inactivates the growth of water contaminating microorganisms are quite complex. The technological application of solar radiation to inactivate microorganisms in water has been termed solar disinfection (SODIS). SODIS treatment involves the exposure of water in transparent colourless vessels to direct sunlight for at least $7 \mathrm{~h}$ on clear sunny days or 2 days in cloudy weather. ${ }^{17,18}$ Ultraviolet(UV)-A, which is the more abundant, active component of solar radiation, has been reported to directly and indirectly target various vital microbial cell components and processes such as transcription and translation, transport systems, metabolism, chaperones and catalase (responsible for counteracting dangerous oxygen radicals), thereby inducing microbial cellular death. ${ }^{19,20}$ UVA has also been reported to cause single-strand breaks in DNA, and conditions that result in such damage have been shown to induce multiplication of CTXФ and, simultaneously, increase the expression of $c t X A B$ genes as a result of the SOS DNA repair response. ${ }^{21}$ The DNA repair response increases the repression of the LeXA protein on the CTXФ promoter $\left(P_{r s t A}\right)$ upstream of the $C t x A B$ gene, through the protease activity of the RecA protein, ${ }^{21}$ thereby enabling its transcription. Even though the $c t x A B$ gene has its own promoter $\left(P_{c t x A B}\right)$, reports have shown that it can be transcribed from CTXФ $P_{r s t A}$. DNA damaging agents, such as mitomycin $C$ and UV light, have been shown to induce multiplication of CTX $\Phi^{\text {rsta }}$ as well as the expression of CT.21,22 Sunlight contains a sufficient dose of UV light and can increase the bacteriophage titre, thereby enabling its transmission to potential recipient strains of $V$. cholerae. ${ }^{23}$ The transmission of CTXФ is, however, dependent on its stability which relies on factors such as the viability of the bacteria, duration of UV exposure and environmental factors such as temperature, salinity and $\mathrm{pH}^{23}$

In this study we investigated the potential for sunlight to induce the secretion of cholera toxin by toxigenic strains of $V$. cholerae by means of solar irradiating the microorganisms in water.

\section{Material and methods}

\section{Vibrio cholerae strains and culture conditions}

Seven strains of $V$. cholerae - six toxigenic and one non-toxigenic - were used in this study: NCTC 5941 and NCTC 12945 obtained from the national collection of type cultures; BRITS01 isolated from Brits, South Africa; G4222 
isolated from a cholera patient in Gauteng, South Africa; ERWATA01 isolated at East Rand Water, Johannesburg, South Africa; ENV1009 isolated at Rand Water (Vereeniging) in South Africa; and UG01 isolated from groundwater in Katojo, Uganda. All strains were stored at $-80{ }^{\circ} \mathrm{C}$ as bacterial stocks on beads. Each strain was cultured on nutrient agar plates by incubation at $37^{\circ} \mathrm{C}$ for $18 \mathrm{~h}$. From each isolate, $2-5$ colonies were inoculated in Luria broth (LB, pH 8.5) and incubated at $37^{\circ} \mathrm{C}$ on a rotary shaker at $200 \mathrm{rpm}$ overnight until the stationary phase was reached. These cultures were used for (1) cholera toxin analysis by an enzyme-linked immunosorbent assay (ELISA), (2) semi-quantitative and qualitative real-time polymerase chain reaction (qRT-PCR) analysis and (3) solar exposures in water because of their resilience, as recommended by Berney et al. ${ }^{24}$

\section{Preparation of Vibrio cholerae for solar exposure}

Vibrio cholerae was harvested by centrifugation (at $3000 \mathrm{rpm}$ for $10 \mathrm{~min}$ ) from overnight stationary phase cultures of the batch cultures grown in LB. The pellet for each strain was washed three times with $1 \times$ phosphate buffered saline (PBS, pH 7.5) to remove all traces of LB and the bacteria were diluted in commercially available still bottled water (Bonaqua, Pretoria, South Africa) to an optical density $\left(\mathrm{OD}_{600 \mathrm{~mm}}\right)$ of 0.1 that corresponded approximately to 11.5 colony forming units (CFU)/mL before SUVR exposure. The unusually high starting dose was used to increase the possibility of detecting the cholera toxin produced by the toxigenic strains of $V$. cholerae.

\section{Exposure to natural solar radiation}

The bacterial suspension $\left(15 \mathrm{~mL}\right.$ ) was transferred into $25-\mathrm{cm}^{3}$ transparent polystyrene unventilated tissue culture flasks. The flasks were exposed to natural sunlight by placing them horizontally on the roof of a building at an elevation of $1400 \mathrm{~m}$ in Pretoria, South Africa (25⒋'50.40"S, $\left.28^{\circ} 16^{\prime} 50.50^{\prime \prime} \mathrm{E}\right)$. Control samples were prepared in a similar manner and placed next to the experimental ones but were protected from direct sunlight by being covered with an opaque ventilated cardboard box. The samples were exposed to SUVR during clear sunny days for either $7 \mathrm{~h}$ or $31 \mathrm{~h}$. The 7-h exposure period was used because it is the optimal recommended time for SODIS and the 31-h period was used to assess for any further production of cholera toxin. Following exposures to SUVR, the samples were prepared for enumeration by the plate count method. Cholera toxin production was assayed using an ELISA and qRT-PCR analysis was used to assess the integrity of the DNA.

\section{Enumeration of Vibrio cholerae}

Bacterial samples exposed to SUVR were serially diluted in sterile $1 \mathrm{x}$ PBS and plated on nutrient agar using the Miles and Misra drop count technique ${ }^{25}$ with slight modifications. Briefly, $10 \mu \mathrm{L}$ of the appropriate dilution was dropped onto sterile nutrient agar plates in quadruplicate. The plates were incubated at $37^{\circ} \mathrm{C}$ for $18-20 \mathrm{~h}$. Plates with fewer than 50 discrete colonies per drop were selected for counting. The total count was divided by the number of drops, multiplied by 100 to convert to $1 \mathrm{~mL}$, and then divided by the dilution factor to give the number of $\mathrm{CFU} / \mathrm{mL} .^{14}$

\section{Ganglioside GM1 cholera toxin ELISA assay}

Materials used for the cholera toxin ELISA were: 96-well ELISA microplates (Greiner Bio-One, LASEC SA Centurion, South Africa); purified choleragenoid rabbit polyclonal IgG horseradish peroxidase (HRP) conjugated antibody (catalogue number PA1-73189) against the B subunit of the cholera toxin (BIOCOM Biotech, Thermo Scientific, Rockford, IL, USA); monosialoganglioside GM1 (G7641-1MG, Sigma, Johannesburg, South Africa) purchased as $1 \mathrm{mg}$ of powder and dissolved in methanol to a final concentration of $1 \mathrm{mg} / \mathrm{mL}$; wash buffer prepared by adding $0.05 \%$ Tween 20 to $1 \times$ PBS; blocking buffer consisting of $1 \%$ bovine serum albumin (BSA) in wash buffer (1\% BSA); and tetramethylbenzidine (TMB) substrate reagent (catalogue number 421101, BioLegend, BIOCOM Biotech, San Diego, CA, USA) prepared and used for colour development according to the manufacturer's instructions. All incubations were done at room temperature $\left(23-25^{\circ} \mathrm{C}\right)$. After each incubation period, the ELISA plate was emptied and washed three times with the wash buffer. To each well in the plate, $100 \mathrm{ng} / \mathrm{mL}$ of ganglioside GM1 in 1 x PBS was added and left overnight (about $15 \mathrm{~h}$ ). The plate was then washed with wash buffer and blocking buffer was added. After $1 \mathrm{~h}$, the plate was emptied, washed and then the supernatants from the solar-irradiated and non-irradiated samples were added. The cholera toxin B subunit and wash buffer were used as positive and negative controls, respectively. After $1.5 \mathrm{~h}$ of incubation, the plate was emptied, washed and the polyclonal rabbit HRP conjugated anti-cholera toxin B subunit antibody (1:1000 dilution in blocking buffer) was added and left for $1 \mathrm{~h}$. The plate was emptied, washed and $100 \mu \mathrm{L}$ of TMB substrate was added to each well. The plate was left at room temperature for 30 min before the stop solution consisting of $100 \mu \mathrm{L}$ of $1 \mathrm{M}$ sulphuric acid was added to the wells. Within $10 \mathrm{~min}$ of adding the stop solution, the plate was read at an $\mathrm{OD}_{450 \mathrm{~nm}}$ in the BioTek Power Wave HT plate reader (BioTek, Winooski, VT, USA). Prior to reading of the plates, the minimum detection ability of the cholera toxin ELISA was determined by using seven tenfold dilutions (from a concentration of $1000000 \mathrm{pg} / \mathrm{mL}$ to $1 \mathrm{pg} / \mathrm{mL}$ ) of the cholera toxin. These results were used to plot a standard curve. All assays were performed in duplicate.

\section{Qualitative and quantitative real-time PCR analysis}

Prior to DNA extraction, overnight bacterial cultures in LB were diluted to a uniform $0 D_{600 \mathrm{~nm}}$ of 1 . Genomic DNA was extracted using the InstaGene Matrix kit (Bio-Rad, Hercules, CA, USA) according to the manufacturer's instructions. RT-PCR was performed using $5 \mu \mathrm{L}$ of the supernatant from each extraction. Two genes - the outer membrane protein gene (ompW) specific to $V$. cholerae and the $c t x$ gene (complex A and B) involved in cholera toxin production - were targeted in the RT-PCR. Two primer sets ${ }^{26-28}$ were used to amplify the ompW and ctXAB gene segments. The classical and El Tor variants of the $\operatorname{tcp} A$ gene were amplified with primers designed by Mukhopadhyay et al. ${ }^{29}$ To distinguish the 01 and 0139 serogroups, the 01 and $0139 \mathrm{rfb}$ genes were targeted with primers published by Hoshino et al. ${ }^{30}$ All the primers used were synthesised at Inqaba Biotech (Pretoria, South Africa) and are shown in Table 1.

Each single-plex RT-PCR amplification reaction contained: 1 x SensiMix HRM reaction buffer (containing dNTPs and $6 \mathrm{mM} \mathrm{MgCl}$ ); $0.2 \mu \mathrm{M}$ primer; heat-activated DNA polymerase; EvaGreen dye (Quantace, London, UK); and $5 \mu \mathrm{L}$ of DNA. Nuclease-free water (Applied Biosystems, Carlsbad, CA, USA) was used to make up the reaction to a final volume of $25 \mu \mathrm{L}$. Amplification was performed in a RotorGene 6000 rotary thermal cycler (5-plex) with high-resolution melting (HRM) capability (Qiagen, Hilden, Germany). The heat-activation step of the DNA polymerase was performed at $95^{\circ} \mathrm{C}$ for 10 min, followed by 45 cycles of DNA denaturation at $95^{\circ} \mathrm{C}$ for $30 \mathrm{~s}$, annealing at $62^{\circ} \mathrm{C}$ for $30 \mathrm{~s}$ and extension at $72{ }^{\circ} \mathrm{C}$ for $30 \mathrm{~s}$. A final extension step was performed at $72{ }^{\circ} \mathrm{C}$ for $5 \mathrm{~min}$.

To differentiate and identify amplification products, HRM curve analysis was performed by lowering the temperature to $60^{\circ} \mathrm{C}$ for $5 \mathrm{~min}$, followed by increasing the temperature to $90{ }^{\circ} \mathrm{C}$ in increments of $0.1{ }^{\circ} \mathrm{C} / \mathrm{s}$. Fluorescence was measured continuously and melting temperature peaks were calculated based on the initial fluorescence curve $(F / T)$ by plotting the negative derivative of fluorescence over temperature versus temperature (-dF/dT versus $\mathrm{T})$.

\section{Statistical analysis}

The measure of the significance of the difference observed between the solar irradiated and non-irradiated samples was determined using the Student's $t$-test; $p<0.05$ was considered statistically significant. 
Table 1: $\quad$ PCR primer sequences used to characterise Vibrio cholerae strains

\begin{tabular}{|c|c|c|c|}
\hline Target gene & Primer & Primer sequences $\left(5^{\prime}-3^{\prime}\right)$ & Reference \\
\hline \multirow{2}{*}{ ompW } & ompW1 & CACCAAGAAGGTGACTTTAATTGTG & \multirow{2}{*}{ Nandi et al. ${ }^{26}$} \\
\hline & ompW3 & GGTTTGTCGAATTAGCTTCACC & \\
\hline \multirow{2}{*}{$c t x A B$} & $\operatorname{ctxAB}-\mathrm{F}$ & GCCGGGTTGTGGGAATGCTCCAAG & \multirow{2}{*}{ Goel et al. ${ }^{27}$} \\
\hline & $\operatorname{ctxAB}-R$ & GCCATACTAATTGCGGCAATCGCATG & \\
\hline \multirow{4}{*}{$\operatorname{tcp} A$} & tcpA-F(Cla) & CACGATAAGAAAACCGGTCAAGAG & \multirow{4}{*}{ Mukhopadhyay et al. ${ }^{29}$} \\
\hline & tcpA-R(Cla) & ACCAAATGCAACGCCGAATGGAGC & \\
\hline & tcpA-F(Elt) & GAAGAAGTTTGTAAAAGAAGAACAC & \\
\hline & tcpA-R(Elt) & GAAAGGACCTTCTTTCACGTTG & \\
\hline \multirow{2}{*}{ Rfb complex (01) } & $01 \mathrm{~F} 2-1$ & GTTTCACTGAACAGATGGG & \multirow{2}{*}{ Hoshino et al. ${ }^{30}$} \\
\hline & 01F2-2 & GGTCATCTGTAAGTACAAC & \\
\hline \multirow{2}{*}{ Rfb complex (0139) } & 0139F2 & AGCCTCTTTATTACGGGTGG & \multirow{2}{*}{ Hoshino et al. ${ }^{30}$} \\
\hline & 0139R2 & GTCAAACCCGATCGTAAAGG & \\
\hline
\end{tabular}

Cla, classical; Elt, El Tor

\section{Results}

\section{Characterisation of the Vibrio cholerae strains}

The seven strains of $V$. cholerae used in this study were characterised by RT-PCR of four different gene targets: the ompW, ctxAB, tcpA (classical and El Tor biotype) and the rfb complex (specific for the 01 and 0139 serogroup). All the $V$. cholerae strains were positive for the ompW gene; only the 1009 strain was negative for the $\operatorname{ctx} A B$ gene (Table 2). However, not all the $c t x A B$ gene positive $V$. cholerae strains belonged to the same serogroup or biotype; three of them - NCTC 5941, G4222, and ERWATA01 - belonged to the 01 serogroup while only one strain, NCTC 12945, was in the 0139 serogroup. The other two strains (UG01, BRITS01) were found to be $\operatorname{ctXAB}$ positive but did not belong to either the 01 or 0139 serogroups; the BRITS01 strain did not harbour any of the $t c p A$ genes while the UG01 strain harboured a hybrid (classical and El Tor) tcpA gene.

Table 2: Real-time PCR characterisation of the seven Vibrio cholerae strains used in this study

\begin{tabular}{l|c|c|c|c|c|c}
\hline \hline Strain & ompW & ctxAB & rfb 01 & $\begin{array}{c}\text { rfb } \\
\mathbf{0 1 3 9}\end{array}$ & $\begin{array}{c}\text { tcpA } \\
\text { classical }\end{array}$ & $\begin{array}{c}\text { tcpA } \\
\text { El Tor }\end{array}$ \\
\hline \hline NCTC 5941 & + & + & + & - & + & - \\
\hline NCTC 12945 & + & + & - & + & - & + \\
\hline BRITS01 & + & + & - & - & - & - \\
\hline G4222 & + & + & + & - & - & + \\
\hline UG01 & + & + & - & - & $+{ }^{*}$ & $+{ }^{*}$ \\
\hline ERWATA01 & + & + & + & - & - & + \\
\hline 1009 & + & - & - & - & - & - \\
\hline
\end{tabular}

*Alternative variant

\section{Exposure of Vibrio cholerae to solar ultraviolet radiation}

Exposure of the seven $V$. cholerae strains to SUVR was done on a sunny day in June (South African winter). The average ( \pm s.d.) minimum and maximum ambient temperatures at the point of exposure were $19.96 \pm 0.65^{\circ} \mathrm{C}$ and $27.25 \pm 1.06{ }^{\circ} \mathrm{C}$, respectively, whereas the water in which the bacteria were irradiated had a temperature of $23.40 \pm 2.00^{\circ} \mathrm{C}$. There was a mean reduction in the culturability of all the exposed strains of $V$. cholerae of $7.5 \pm 0.81 \log _{10} \mathrm{CFU} / \mathrm{mL}$ from an average initial level of $11.02 \pm 0.69 \log _{10} \mathrm{CFU} / \mathrm{mL}$ after $7 \mathrm{~h}$ of exposure. The two toxigenic strains (NCTC 5941 and 12945) were non-culturable after exposure for a further $24 \mathrm{~h}$ (Figure 1). The lack of total inactivation was expected because an unusually high dose of the microorganism ( $11 \log \mathrm{CFU} / \mathrm{mL})$ was used initially to increase the odds of detecting any cholera toxin secreted.

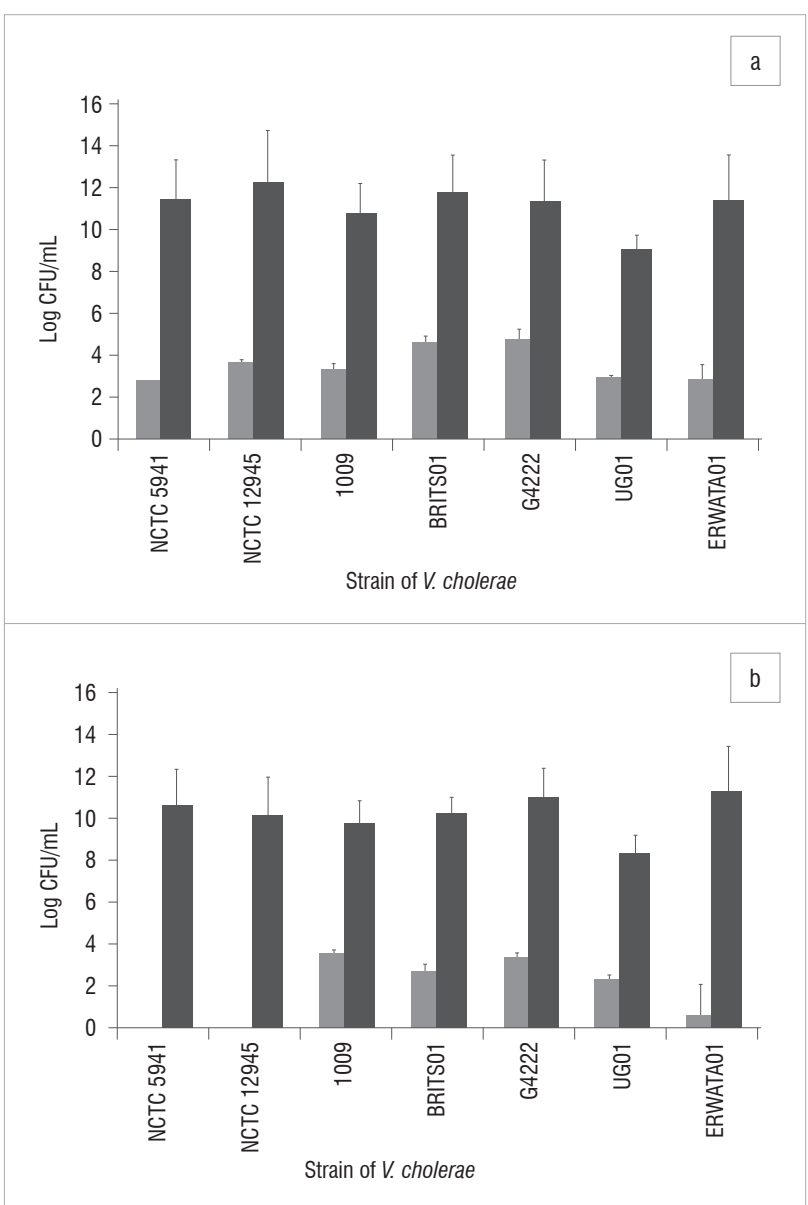

Figure 1: Log CFU/mL counts of solar-irradiated ( $\square$ ) and non-irradiated (ם) strains of Vibrio cholerae after (a) $7 \mathrm{~h}$ and (b) $31 \mathrm{~h}$. Error bars indicate the standard deviation of triplicate experiments. 


\section{Relative quantification of the ctXAB gene}

A quantitative RT-PCR of the $c t x A B$ gene relative to the ompW housekeeping gene was done for each of the $c t x A B$-positive $V$. cholerae strains (those that were cultured at $37^{\circ} \mathrm{C}$ for $15 \mathrm{~h}$ in LB). On average, the crossing point for the ompW gene amplification of all the strains was 22.06 with the difference between the lowest and highest CT being 3.6 cycles. To control for possible cell copy number differences in each qRT-PCR, CT values of the $c t x A B$ gene for each strain were normalised using the ompW CT values for the same strain (using the same DNA extraction from overnight cultures, diluted to an $\mathrm{OD}_{600 \mathrm{~nm}}$ of 1 ). The average crossing point for the $\operatorname{ct} A B$ gene for all the $c t x A B$-positive strains was 14.58 with a difference of 10.2 cycles between the lowest and highest CT value (Table 3). The ctXAB gene in the isolate from BRITS required an additional 9.8 cycles of amplification compared to all the other toxigenic strains. HRM analysis showed that the $c t x A B$ amplicon from the BRITS01 strain was very similar to that of the other toxigenic strains (unpublished data). The solar-irradiated samples showed higher CT values in comparison with the non-solar exposed ones (Table 3). Following $7 \mathrm{~h}$ of exposure, the $\operatorname{ctx} A B$ gene crossing point for all the toxigenic strains occurred on average 0.6 cycles $(p=0.027)$ earlier for the controls than for the experimental samples. The same was observed for the ompW gene but with a slight decrease in the number of cycles ( 0.47 cycles, $p=0.182)$. This result translated into an approximate $20 \%$ reduction in amplifiable DNA after $7 \mathrm{~h}$ of solar exposure relative to the non-solar exposed samples. After $31 \mathrm{~h}$ of exposure the crossing point for the $c t X A B$ and ompW genes occurred $1.75(p=0.0012)$ and $1.27(p=0.021)$ cycles earlier, respectively, for the controls compared with the exposed samples, which translated into a $50 \%$ reduction in amplifiable DNA in the solar-irradiated samples when compared with the non-irradiated ones. The percentage reduction in amplifiable DNA was based on results obtained through qRT-PCR of serial dilutions of $V$. cholerae based on the ompW gene (unpublished data).

\section{Secretion of cholera toxin}

The standard curve for the cholera toxin ELISA is shown in Figure 2. On average none of the negative controls (wash buffer) yielded an $\mathrm{OD}_{450 \mathrm{~mm}}$ of more than $0.052 \pm 0.002$ (mean \pm s.d.). The mean \pm s.d. $0 D_{450 \mathrm{~mm}}$ for cholera toxin at a concentration of $1 \mathrm{pg} / \mathrm{mL}$ for this assay was found to be $0.056 \pm 0.003$, while the mean $\pm s . d D_{450 n m}$ for a concentration of $10 \mathrm{pg} / \mathrm{mL}$ was $0.081 \pm 0.009$. On this basis, an OD of 0.081 corresponding to a cholera toxin (sample : negative control) ratio of 1.45 or greater was selected as the cut-off value for what was considered positive for cholera toxin secretion. ${ }^{31}$ The six toxigenic and one nontoxigenic strains of $V$. cholerae were tested for their ability to secrete cholera toxin in the culture medium. After $15 \mathrm{~h}$ of incubation at $37^{\circ} \mathrm{C}$, the biomass (determined by the $\mathrm{OD}_{600 \mathrm{~mm}}$ reading) increased on average from 0.001 to $1.481 \pm 0.12 \mathrm{OD}_{600 \mathrm{~m}}$ units with visible biofilm formation in $V$. cholerae isolates obtained from Uganda (UG01) and South Africa (ENV1009, G4222, BRITS01). Of all the isolates assessed in this study, only three (G4222, UG01 and NCTC 129450) produced cholera toxin in the culture medium under laboratory conditions (Table 4).

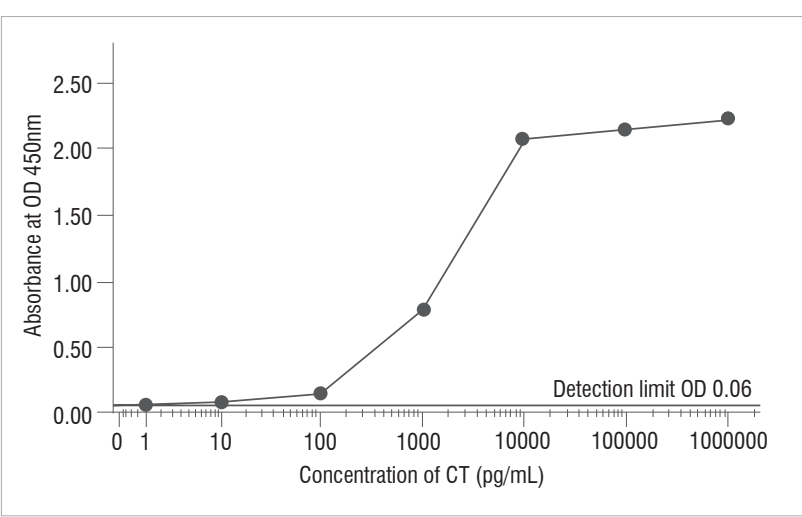

Figure 2: Standard curve of CT-B subunit determined by ELISA. Each point is a mean of duplicate experiments.

Table 4: Cholera toxin ELISA ratio (sample : negative control)

\begin{tabular}{l|c|c|c|c|c}
\hline \hline \multirow{2}{*}{ Strain } & \multirow{2}{*}{ Luria broth } & \multicolumn{2}{|c|}{$7 \mathrm{~h}$} & \multicolumn{2}{c}{$31 \mathrm{~h}$} \\
\cline { 3 - 6 } & & Exposed & Control & Exposed & Control \\
\hline \hline NCTC 5941 & 1.147 & 1.029 & 0.933 & 0.990 & 0.960 \\
\hline NCTC 12945 & 12.094 & 1.038 & 0.971 & 0.904 & 1.040 \\
\hline BRITS01 & 0.918 & 0.942 & 0.981 & 0.865 & 0.940 \\
\hline UG01 & 3.145 & 1.077 & 0.942 & 1.125 & 1.020 \\
\hline G4222 & 41.147 & 0.856 & 0.856 & 0.952 & 0.910 \\
\hline ERWATA01 & 1.004 & 1.154 & 1.029 & 0.942 & 1.030 \\
\hline 1009 & 0.908 & 1.038 & 0.913 & 1.000 & 0.940 \\
\hline
\end{tabular}

Note: Control samples were not solar irradiated.

The other strains had a cholera toxin ELISA (sample : negative control) ratio of below 1.45 units and hence were considered negative for cholera toxin secretion. Following exposure to SUVR, the secretion of $\mathrm{CT}$ by exposed and non-exposed samples was assessed after $7 \mathrm{~h}$ and after $31 \mathrm{~h}$. There were no detectable levels of cholera toxin in either the exposed or non-exposed samples at both time points, with none of the samples showing a sample : negative control ratio of 1.45 or more.

\section{Discussion and conclusions}

As a means of mitigating the contraction of waterborne diseases or deaths resulting from the consumption of untreated water, the use of SUVR through a technique known as SODIS has been recommended. We investigated the effect of SUVR on the secretion of cholera toxin by V. cholerae.

Table 3: Crossing point values of $c t x A B$ and ompW genes of Vibrio cholerae strains after $7 \mathrm{~h}$ or $31 \mathrm{~h}$ of exposure to solar UV radiation

\begin{tabular}{|c|c|c|c|c|c|c|c|c|c|}
\hline \multirow[b]{2}{*}{ Strain } & \multirow{2}{*}{$\begin{array}{c}c t x A B^{\star} \\
\text { (in Luria broth) }\end{array}$} & \multicolumn{4}{|c|}{$7 \mathrm{~h}$} & \multicolumn{4}{|c|}{$31 \mathrm{~h}$} \\
\hline & & $\begin{array}{l}\text { Exposed } \\
c t x A B\end{array}$ & $\begin{array}{l}\text { Control } \\
\text { ctxAb }\end{array}$ & $\begin{array}{c}\text { Exposed } \\
\text { ompW }\end{array}$ & $\begin{array}{l}\text { Control } \\
\text { ompW }\end{array}$ & $\begin{array}{l}\text { Exposed } \\
c t x A B\end{array}$ & $\begin{array}{l}\text { Control } \\
c t x A b\end{array}$ & $\begin{array}{l}\text { Exposed } \\
\text { ompW }\end{array}$ & $\begin{array}{l}\text { Control } \\
\text { ompW }\end{array}$ \\
\hline NCTC 5941 & 11.2 & 16.5 & 16.0 & 23.5 & 23.5 & 17.0 & 15.0 & 24.0 & 23.0 \\
\hline NCTC 12945 & 11.5 & 18.0 & 17.0 & 27.0 & 25.0 & 20.0 & 17.0 & 27.0 & 24.0 \\
\hline BRITS01 & 21.4 & 28.0 & 26.5 & 26.0 & 24.0 & 27.5 & 26.0 & 25.0 & 24.0 \\
\hline G4222 & 11.9 & 21.0 & 21.0 & 27.0 & 27.0 & 19.5 & 18.5 & 26.5 & 25.0 \\
\hline UG01 & 11.6 & 15.0 & 15.0 & 23.0 & 23.0 & 16.0 & 14.0 & 23.2 & 23.0 \\
\hline ERWATA01 & 11.6 & 21.4 & 20.8 & 27.0 & 28.0 & 20.0 & 19.0 & 26.0 & 25.8 \\
\hline
\end{tabular}

Note: Control samples were not solar irradiated. All exposures were in water except those indicated by * 
The pathogenicity of $V$. cholerae has been linked to only two key virulence factors - toxin co-regulated pili (TCP) and cholera toxin. ${ }^{32}$ We used seven strains of $V$. cholerae, of which six harboured the genes responsible for cholera toxin production (Table 2). Four of the ctxAB-positive strains of $V$. cholerae contained the tcpA gene while the other two strains (UG01, Brits) were negative for both the rfb01 and rfb0139 genes (Table 2). The latter were then categorised as non-01/0139 toxigenic strains of $V$. cholerae. The UG01 strain could not be characterised as either El Tor or classical as it was found to be positive for both tcpA genes. It is possible that this strain of $V$. cholerae is an El Tor/classical hybrid strain. El Tor variants of the $01 / 0139 \mathrm{~V}$. cholerae have been isolated from Asia and Africa ${ }^{33,34}$ but there is no report on the existence of altered El Tor variants that are non-01/0139. The other non-01/0139 toxigenic strain (BRITS01) did not contain the tcpA gene, meaning that CTXФ may have found an alternative route into this strain. Besides horizontal gene transfer, the current theory is that the TCP was the only route through which СТХФ could gain access into the V. cholerae cell. However, recent studies by Campos et al. ${ }^{35,36}$ have shown that two novel filamentous bacteriophages (VEJ $\Phi$ and VGJ $\Phi$ ) could also be used to transduce CTXФ amongst $V$. cholerae strains that express the mannose-sensitive haemagglutinin (MSHA) receptor. The MSHA receptor is ubiquitously expressed on the surface of many $V$. cholerae strains and the identification of these novel bacteriophages may explain the existence of non-01/0139 strains of $V$. cholerae containing CTХФ. Furthermore, this may also explain the sporadic cholera outbreaks that have recently been attributed to non-01/0139 strains of $V$. cholerae. . $^{37,38}$ Therefore the developments of affordable early detection systems for $V$. cholerae in the environment are necessary to prevent cholera outbreaks.

Exposure of the toxigenic strains of $V$. cholerae to SUVR showed that the bacteria did not produce detectable amounts of the cholera toxin in the water. Furthermore, the RT-PCR results confirmed that the integrity of the DNA significantly deteriorated as the quality of amplifiable DNA decreased (Table 3 ). These findings are contrary to what has been observed by other researchers in regard to cholera toxin secretion. Quinones et al. ${ }^{21,22}$ reported that the SOS DNA repair resulting from DNA damaging agents such as UV light induced the multiplication of CTXФ and increased the expression of cholera toxin. Similarly, Faruque et al. ${ }^{23}$ showed that the exposure of $V$. cholerae to sunlight resulted in an increase of viral titres, which has also been linked to cholera toxin production. ${ }^{21,22}$ Solar radiation contains UV light which is a DNA damaging agent ${ }^{19,20}$ and hence could initiate the SOS DNA repair thereby increasing multiplication of CTXФ as well as expression of cholera toxin. However, both these studies exposed $V$. cholerae to conditions containing a DNA damaging agent in a nutrient-rich environment and for shorter periods. It is also known that a nutrient-rich environment is capable of counteracting the oxygen radicals responsible for the deleterious effects on the microbial cell membrane, which thereby reduces the impact of SUVR on cellular targets. ${ }^{39}$ These findings suggest that cells that have undergone cellular damage as a result of SUVR in a nutrient-rich environment are capable of repairing themselves. In our study, all $V$. cholerae strains were solar irradiated for longer periods in water that could be regarded as a nutrientpoor environment. Therefore the bacterial cells received a full dosage of SUVR and were afforded no protection in comparison with cells growing in a nutrient-rich medium.

In conclusion, we have shown that the exposure of toxigenic strains of $V$. cholerae to SUVR, as recommended for SODIS, reduces the quantity of amplifiable DNA and inactivates the culturability of these microorganisms..$^{14}$ However, the major finding from this study was the inability of the pathogenic strains of $V$. cholerae to secrete cholera toxin above the baseline detection limit following SUVR. The detection limit used in this study $(10 \mathrm{pg} / \mathrm{mL})$ was lower than the lethal dose $\left(\mathrm{LD}_{50}\right)$ of $250 \mu \mathrm{g}$ of cholera toxin needed to cause cholera in mice..$^{40}$ This finding is encouraging to communities that may rely on SODIS for drinking water as a short-term intervention, especially in places where cholera outbreaks are frequent.

\section{Acknowledgements}

We thank Dr Eugenia Barros for providing some of the reagents used in the study.

\section{Authors' contributions}

M.P. was the project leader and made conceptual contributions. C.C.S. and W.J. were responsible for the design and execution of the experiments. C.C.S. conceptualised the study and wrote the manuscript.

\section{References}

1. Blow NS, Salomon RN, Garrity K, Reveillaud I, Kopin A, Jackson FR, et al. Vibrio cholerae infection of Drosophila melanogaster mimics the human disease cholera. PLoS Pathog. 2005;1(1):e8. http://dx.doi.org/10.1371/ journal.ppat.0010008

2. World Health Organization (WHO). Progress on drinking water and sanitation: 2012 update. Geneva/New York: WHO/United Nations Children's Fund; 2012. p. 58. Available from: http://www.who.int/water_sanitation health/ publications/2012/jmp_report/en/index.html

3. World Health Organization (WHO). Outbreak bulletin. Geneva: WHO; 2011 p. 5. Available from: http://www.afro.who.int/en/clusters-a-programmes/dpc/ epidemic-a-pandemic-alert-and-response/outbreak-news/3066-outbreakbulletin-vol-1-issue-2-july-19-2011.html

4. Siddique AK, Akram K, Zaman K, Mutsuddy P, Eusof A, Sack RB. Vibrio cholerae 0139: How great is the threat of a pandemic? Trop Med Int Health. 1996;1(3):393-398. http://dx.doi.org/10.1046/j.1365-3156.1996.d01-54.x

5. World Health Organisation (WHO). 1998-Cholera-Vibrio cholerae 0139 strain. Geneva: WHO; 1998. Available from: http://www.who.int/csr/ don/1998_09_22/en/index.htmL

6. Nasreldin E, Layla B, Mohammed A, Burhan I, Faisal A, Obeid ET, et al Molecular characterization of Vibrio cholerae non-01/non-0139 isolated from coastal water of Arabian Gulf. Afr J Microbiol Res. 2012;6(2):447-452.

7. Sheikh AF, Goodariza H, Aslani S. Identification of Vibrio cholerae pathogenicity island (ctxA, OmpW and tcpA) in non-0139 and non-01 V. cholerae strains isolated from Karun River in Ahvaz, Iran. Afr J Microbiol Res. 2012;6(6):1185-1189.

8. Aliabad NH, Bakhshi B, Pourshafie MR, Sharifnia A, Ghorbani M. Molecular diversity of CTX prophage in Vibrio cholerae. Lett Appl Microbiol. 2012;55(1):27-32. http://dx.doi.org/10.1111/j.1472-765X.2012.03253.x

9. Mekalanos JJ. Duplication and amplification of toxin genes in Vibrio cholerae. Cell. 1983;35(1):253-263. http://dx.doi.org/10.1016/0092-8674(83)90228-3

10. Sanchez J, Holmgren J. Cholera toxin structure, gene regulation and pathophysiological and immunological aspects. Cell Mol Life Sci. 2008;65(9):1347-1360. http://dx.doi.org/10.1007/s00018-008-7496-5

11. Aoki H, Wu H, Nakano T, Ooi Y, Daikoku E, Kohno T, et al. Nanotransportation system for cholera toxin in Vibrio cholerae 01. Med Mol Morphol. 2009;42(1):40-46. http://dx.doi.org/10.1007/s00795-008-0431-x

12. Berney M, Weilenmann HU, Simonetti A, Egli T. Efficacy of solar disinfection of Escherichia coli, Shigella flexneri, Salmonella Typhimurium and Vibrio cholerae. J Appl Microbiol. 2006;101(4):828-836. http://dx.doi.org/10.1111/ j.1365-2672.2006.02983.x

13. Bosshard F, Berney M, Scheifele M, Weilenmann H-U, Egli T. Solar disinfection (SODIS) and subsequent dark storage of Salmonella typhimurium and Shigella flexneri monitored by flow cytometry. Microbiology. 2009;155(4):1310 1317. http://dx.doi.org/10.1099/mic.0.024794-0

14. Ssemakalu CC, Pillay M, Barros E. The effect of solar ultraviolet radiation and ambient temperature on the culturability of toxigenic and non-toxigenic Vibrio cholerae in Pretoria, South Africa. Afr J Microbiol Res. 2012;6(30):59575964. http://dx.doi.org/10.5897/AJMR12.601

15. Conroy RM, Meegan ME, Joyce T, McGuigan K, Barnes J. Solar disinfection of drinking water protects against cholera in children under 6 years of age. Arch Dis Child. 2001;85(4):293-295. http://dx.doi.org/10.1136/adc.85.4.293

16. Du Preez M, McGuigan KG, Conroy RM. Solar disinfection of drinking water in the prevention of dysentery in South African children aged under 5 years: The role of participant motivation. Environ Sci Technol. 2010;44(22):8744-8749. http://dx.doi.org/10.1021/es103328j 
17. Boyle M, Sichel $C$, Fernández-Ibáñez P, Arias-Quiroz GB, Iriarte-Puña M, Mercado A, et al. Bactericidal effect of solar water disinfection under real sunlight conditions. Appl Environ Microbiol. 2008;74(10):2997-3001. http:// dx.doi.org/10.1128/AEM.02415-07

18. Ubomba-Jaswa E, Boyle MAR, McGuigan KG. Inactivation of enteropathogenic E. coli by solar disinfection (SODIS) under simulated sunlight conditions. $\mathrm{J}$ Phys Conf Ser. 2008;101:012003. http://dx.doi.org/10.1088/1742$6596 / 101 / 1 / 012003$

19. Bosshard F, Bucheli M, Meur Y, Egli T. The respiratory chain is the cell's Achilles' heel during UVA inactivation in Escherichia coli. Microbiology 2010;156(7):2006-2015. http://dx.doi.org/10.1099/mic.0.038471-0

20. Bosshard F, Riedel K, Schneider T, Geiser C, Bucheli M, Egli T. Protein oxidation and aggregation in UVA-irradiated Escherichia coli cells as signs of accelerated cellular senescence. Environ Microbiol. 2010;12(11):29312945. http://dx.doi.org/10.1111/j.1462-2920.2010.02268.x

21. Quinones M, Davis BM, Waldor MK. Activation of the Vibrio cholerae SOS response Is not required for intestinal cholera toxin production or colonization. Infect Immun. 2006;74(2):927-930. http://dx.doi.org/10.1128/IAI.74.2.927930.2006

22. Quinones M, Kimsey HH, Ross W, Gourse RL, Waldor MK. LexA represses CTXФ transcription by blocking access of the C-terminal domain of RNA polymerase to promoter DNA. J Biol Chem. 2006;281(51):39407-39412. http://dx.doi.org/10.1074/jbc.M609694200

23. Faruque SM, Asadulghani, Rahman MM, Waldor MK, Sack DA. Sunlightinduced propagation of the lysogenic phage encoding cholera toxin. Infect Immun. 2000;68(8):4795-4801. http://dx.doi.org/10.1128/IAl.68.8.47954801.2000

24. Berney M, Weilenmann H-U, Egli T. Flow-cytometric study of vital cellular functions in Escherichia coli during solar disinfection (SODIS). Microbiology. 2006;152(6):1719-1729. http://dx.doi.org/10.1099/mic.0.28617-0

25. Miles AA, Misra SS, Irwin J0. The estimation of the bactericidal power of the blood. J Hyg (Lond). 1938;38(6):732-749. http://dx.doi.org/10.1017/ S002217240001158X

26. Nandi B, Nandy RK, Mukhopadhyay S, Nair GB, Shimada T, Ghose AC. Rapid method for species-specific identification of Vibrio cholerae using primers targeted to the gene of outer membrane protein $0 \mathrm{mpW}$. J Clin Microbiol. 2000;38(11):4145-4151.

27. Goel AK, Tamraker A, Nema V, Kamboj D, Singh L. Detection of viable toxigenic Vibrio cholerae from environmental water sources by direct cell duplex PCR assay. World J Microbiol Biotechnol. 2005;21(6-7):973-976. http://dx.doi.org/10.1007/s11274-004-7317-4

28. Le Roux WJ, Van Blerk GN. Use of a high resolution melt real-time polymerase chain reaction (PCR) assay for the environmental monitoring of Vibrio cholerae. Afr J Microbiol Res. 2011;5(21):3520-3526.
29. Mukhopadhyay AK, Chakraborty S, Takeda Y, Nair GB, BergDE. Characterization of VPI pathogenicity island and CTXphi prophage in environmental strains of Vibrio cholerae. J Bacteriol. 2001;183(16):4737-4746. http://dx.doi. org/10.1128/JB.183.16.4737-4746.2001

30. Hoshino K, Yamasaki S, Mukhopadhyay AK, Chakraborty S, Basu A Bhattacharya SK, et al. Development and evaluation of a multiplex PCR assay for rapid detection of toxigenic Vibrio cholerae 01 and 0139. FEMS Immunol Med Microbiol. 1998;20(3):201-207. http://dx.doi.org/10.1111/j.1574695X.1998.tb01128.x

31. Centers for Disease Control and Prevention (CDC). Laboratory methods for the diaganosis of Vibrio cholerae. Atlanta, GA: CDC; 2012. Available from: http://www.cdc.gov/cholera/laboratory.htmL

32. Davis BM, Waldor MK. Filamentous phages linked to virulence of Vibrio cholerae. Curr Opin Microbiol. 2003;6(1):35-42. http://dx.doi.org/10.1016/ S1369-5274(02)00005-X

33. Hasan NA, Choi SY, Eppinger M, Clark PW, Chen A, Alam M, et al. Genomic diversity of 2010 Haitian cholera outbreak strains. Proc Natl Acad Sci USA. 2012;109(29):E2010-E2017. http://dx.doi.org/10.1073/pnas.1207359109

34. Taneja N, Mishra A, Sangar G, Singh G, Sharma M. Outbreaks caused by new variants of Vibrio cholerae $01 \mathrm{El} \mathrm{Tor,} \mathrm{India.} \mathrm{Emerg} \mathrm{Infect} \mathrm{Dis.} \mathrm{2009;15(2):352-}$ 354. http://dx.doi.org/10.3201/eid1502.080943

35. Campos J, Martinez E, Marrero K, Silva Y, Rodriguez BL, Suzarte E, et al. Novel type of specialized transduction for CTXФ or its satellite phage RS1 mediated by filamentous phage VGJФ in Vibrio cholerae. J Bacteriol. 2003;185(24):7231-7240. http://dx.doi.org/10.1128/JB.185.24.72317240.2003

36. Campos J, Martinez E, Izquierdo Y, Fando R. VEJФ, a novel filamentous phage of Vibrio cholerae able to transduce the cholera toxin genes. Microbiology. 2010;156(1):108-115. http://dx.doi.org/10.1099/mic.0.032235-0

37. Kirschner AKT, Schlesinger J, Farnleitner AH, Hornek R, Süß B, Golda B, et al. Rapid growth of planktonic Vibrio cholerae non-01/non-0139 strains in a large alkaline lake in Austria: Dependence on temperature and dissolved organic carbon quality. Appl Environ Microbiol. 2008;74(7):2004-2015. http://dx.doi.org/10.1128/AEM.01739-07

38. Nasreldin E, Layla B, Mohammed A, Burhan I, Faisal A, Obeid ET, et al. Molecular characterization of Vibrio cholerae non-01/non-0139 isolated from coastal water of Arabian Gulf. Afr J Microbiol Res. 2012;6(2):447-452.

39. Navntoft C, Ubomba-Jaswa E, McGuigan KG, Fernández-Ibáñez P. Effectiveness of solar disinfection using batch reactors with non-imaging aluminium reflectors under real conditions: Natural well-water and solar light. J Photochem Photobiol B Biol. 2008;93(3):155-161. http://dx.doi. org/10.1016/j.jphotobiol.2008.08.002

40. Gill DM. Bacterial toxins: A table of lethal amounts. Microbiol Rev. 1982;46(1):86-94. 